URSZULA KOSIŃSKA

https://orcid.org/0000-0002-8297-978X

Faculty of History, University of Warsaw

\title{
THE WINDING PATHS OF RUSSIAN IMPERIAL POLITICS: ON DIE GEBURT DES RUSSLÄNDISCHEN IMPERIUMS: HERRSCHAFTSKONZEPTE UND -PRAKTIKEN IM 18.JAHRHUNDERT BY RICARDA VULPIUS*
}

\begin{abstract}
A bstra ct: The article discusses the book Die Geburt des russländischen Imperiums by Ricarda Vulpius, a publication that tracks the emergence of the conceptual background for governing the growing Russian Empire in the eighteenth century, when territorial gains rendered the country increasingly multinational, multi-faith and multicultural. In this paper, the book was treated as an inspiration for examining the relationship between the practices employed by Russia on newly acquired territories in the east and south of Asia, described by Vulpius in the book, and the Russian Empire's policy towards Poland. Key w ords: Russia, Polish-Lithuanian Commonwealth, eighteenth century history, governing strategies, Russian imperialism.
\end{abstract}

The book Die Geburt des russländischen Imperiums. Herrschaftskonzepte und -praktiken im 18. Jahrhundert by Ricarda Vulpius, published in 2020, was first presented in 2018 as the scholar's habilitation thesis at the Faculty of History and the Arts of the Ludwig Maximilian University of Munich(Fakultät für Geschichts- und Kunstwissenschaften der Ludwig-Maximilians-Universität München). The author discusses the concepts and practices of the administration of the eighteenth century Russian Empire, treating the symbolic date of 1721 (when Tsar Peter I was officially proclaimed emperor) as the turning point in the building of the said empire.

The work's central thesis is as follows: Peter I succeeded as the creator of the Russian Empire by absorbing the ideas of the early Enlightenment, including the discourse that brought forth the imperative of

\footnotetext{
*Vienna, Cologne and Weimar: Böhlau, 2020, 610 pp.
} 
'civilizing' non-Christian ethnic groups. The author claims that the ideal of the Russian subject became a civilizational model that Peter I transmitted further east and south, independently of the fact that at the same time, the tsar himself gave his subjects the task of 'self-civilization', that is pursuing their own development (pp.17-18). Vulpius claims: 'the long-term objective of the transformation was to [...] overcome the civilizational deficits of various ethnic groups Russia had recently subjugated on the one hand, and to integrate said groups with the Russian and Russian-speaking population of the country, that is to merge the imperial territory with the territory of a uniform Russian state. ${ }^{1}$ The author notices that in the process of empire-building, the centre used different governing practices in different peripheries due to heterogeneous legal structures and a significant variation in the centre's approach to different regions. Vulpius decided to focus on the Russian conceptions and practices of rule over non-Russian and non-Christian ethnic groups in the Russian Empire. The Russian metropole, convinced of its civilizational superiority, tried to profoundly change the lives of these groups in the eighteenth century following its own interests (p.30). Consequently, the author's research scope excludes the territories Russia gained in the eighteenth century inhabited by Christian yet non-Eastern-Orthodox populace (such as Roman Catholics, Greek Catholics, and Lutherans) - the territories seized from Poland, Courland, Livonia, and Estonia. Vulpius also formulates a thesis that is paradoxical in the light of her initial assumption about the significance of the eighteenth century for the emergence of the Russian Empire. Namely, the scholar claims that the course of development that eighteenth century Russia underwent is ultimately not unique. The analysis of the line of thinking and actions undertaken by the authorities displays numerous similarities to the colonial practices of other European countries. The only phenomenon that Vulpius considers Russian-specific is the early origin of the Russian idea of assimilation and its subsequent connection to the Russian civilizing tendencies. It should, however, be noted that the author does not perform a comparative analysis of the methods employed by the tsars and those practiced by other states in their colonies.

The first question is, why did the author consider the eighteenth century crucial for investigating the titular problem - namely, the birth of the Russian Empire? The book covers the period from Peter's

1 'Das langfristige Ziel dieser Transformation war es [...] zum einen das wahrgenommene Defizit an Zivilisiertheit zu überwinden, zum anderen die verschiedenen etnischen Gruppen mit dem russischen oder russländisch akkulturierten Staatsvolk zu verschmelzen und damit den imperialen Raum mit dem Raum eines russisch geprägten Einheitsstaates zu fusionieren', Vulpius, pp. 19-20. 
coronation as emperor in 1721 to the death of Catherine II in 1797. As Ricarda Vulpius tries to convince the readers that it was then that the Russian elites significantly changed their ways of thinking and their governing practices. This transformation introduced terms like 'empire', 'barbarism', and 'civilization' and prompted the Russian elites to consider the imperial idea as their own and developed an imperial self-awareness of the multi-ethnic society inhabiting the country. However, in her argument, Vulpius fails to prove the unique significance of this particular period. The subject matter evidently cannot be limited to the narrow chronological framework she applies - in terms of territorial expansion, a significant ideological turning point did not mark the eighteenth century. The expansion neither began nor ended at that time, although it has to be noted that the century proved spectacularly successful for Russia in that respect. The eighteenth century was also not a major breakthrough in the national context - Muscovite Russia began subjugating numerous non-Slavic and non-Christian nations (that are of particular interest to the author) in the sixteenth century: Tatars, Kazakhs, Kalmyks, Kabardians, Bashkirs, Yakuts and so on. This process did not end in the eighteenth century. If anything, the eighteenth century bears a special significance in the context of the 'absorption' of lands inhabited by non-Eastern-Orthodox Christian nations (the Lutherans from Courland, Livonia, Estonia; the Roman Catholics and Greek Catholics from territory seized from Poland and Lithuania). However, this process also started earlier - in the seventeenth century when Russia annexed Left-bank Ukraine and the Smolensk region, both inhabited by many Greek and Roman Catholics. As it turns out, to discuss the origins of the basic terms and concepts related to government, the relationship between the authorities and the subjects, or the governing practices, the author needs to reach much deeper - mostly to the sixteenth century, sometimes even to the fifteenth century; in many instances, Vulpius also writes about the nineteenth century. ${ }^{2}$

The book consists of a foreword, a chapter as a methodological introduction, and three subsequent chapters discussing the key issues. These include subjecthood in Russia, the tradition of hostage-taking, and the civilizatory and unificatory mission of Russia, executed through means such as the construction of fortification lines, a state-led missionary action, settlement policies aimed at nomadic peoples, populating empty territories, and the transformation of pre-existing social structures and

${ }^{2}$ For example, in the chapter about the significance of Christianization and, more broadly, religious politics in the building of the empire, only 24 out of 40 pages actually pertain to the eighteenth century. 
customary laws of the conquered groups. The final part of the book contains a summary of the research results. The book also includes an extensive bibliography, a list of sources, illustrations, indices of persons, and 'geographical and ethnic terms'.

In the introductory Chapter 1 , Vulpius presents the subject matter, the terminology, the most crucial research questions, and the theoretical bases for the methodology applied. The scholar situates her studies within post-colonial studies and declares a 'multi-perspectival approach' that will take the voices of non-Russian peoples of the empire into account. The author also briefly discusses the current state of research (suggesting her earlier work, Das Imperium als Thema der russischen Geschichte, for further reading) (p. 42, note 103) and the sources she chose. The literature on the subject Vulpius used represents a broad scope of disciplines: history, but also political science, ethnography, and even lexical research. The author exhibits a strong predilection for works by scholars based in Western Europe, the US, and Russia ${ }^{3}$ - the bibliography includes no works by historians from Poland, ${ }^{4}$ Lithuania, or Ukraine; there are very few items written by scholars representing the Asian nations conquered by Russia. Linguistic limitations most likely cause this; it should, however, be noted that most sources selected by Vulpius present the politics of the empire rather than the perspective of the conquered nations.

The primary source material is limited to publications - primarily Russian and Soviet sborniki dokumentov, that is editions of originally Russian sources and sources about non-Russian nations of the Empire in Russian selection and translation. The author understands that many of them (for example SIRIO, Polnoe sobranie zakonov Rossiiskoi Imperii) include a biased selection that distorts the historical reality (p. 46). However, the scholar has not conducted her own archival research. Another vital group of sources is reports and accounts of travels through Russia and the empire given by Russians and state officials, in some cases also by foreigners who had other reasons for their visit - these do not include, for instance, the seventeenth and eighteenth century accounts given by Polish prisoners of war and exiles. ${ }^{5}$ This selection results in a strongly Russocentric analysis - given the subject matter of Vulpius's

${ }^{3}$ The bibliography is almost 70 pages long (pp. 519-93). It mainly includes sources in German, Russian, and English, occasionally also French.

${ }^{4}$ With an exception of one item by Izabella Zatorska, the dictionaries Stownik staropolski and Słownik polszczyzny XVI wieku, and one book about Poland by Klaus Zernack.

${ }^{5}$ For instance: Mieczysław Wieliczko, Jeniectwo wojenne Polaków w Rosji w latach 1503-1918, Lublin, 1998; the problem is discussed in detail in Agata Roćko, Pamiętniki polskich zesłańców na Syberię w XVIII wieku, Olsztyn, 2001. 
work, understandably so. Nonetheless, the conclusions the author draws rarely give voice to the nationals of states that the Russian Empire annexed. Significantly, the author does at times describe Russian activity as 'conquest', 'annexation' or 'seizure of territory' - however, in most instances, Vulpius uses terms that downplay the brutality of historical events (perhaps the scholar unwittingly adopts the vocabulary of secondary sources): 'incorporation', 'inclusion in the Russian Empire', 'accession', 'integration' and 'mutual relations'.

The author is interested in the concepts of government in Russia's vast territory and the thinking behind it. To scrutinize these problems, Vulpius performs a semantic analysis of terms like 'border', 'colonialism', 'colonization', 'imperialism', 'empire', and 'nation' - both in the political and ethnic sense. The scholar also offers extensive theoretical analysis, for example examines the difference between Kolonisierung and Kolonialisierung - as Vulpius concludes, not every imperial state is a colonial one. The characteristics of colonial power include external control, a sense of civilizational superiority, and an effort to acculturate the dominated nations. As Vulpius concludes using these criteria, Russia undoubtedly can be considered a colonial state, even though the empire had no overseas colonies and adopted a policy of Binnekolonisation - internal colonization - instead. The scholar also deliberates whether the building of the Russian Empire was based on 'gewaltsame Eroberung' or 'friedliche Aneignung' (p.27), but offers no definite opinion of her own on the matter and does not describe the process of territorial acquisition.

Another analysis is the comparison between the terms ruskii and rossiiskii. According to Vulpius, the former was used in the context of language and faith (russische Sprache, russisch-orthodoxer Glaube), the latter of land, state, the empire (russländisch, Rossiiskaia imperiia) (p. 39). The scholar makes one completely erroneous claim here - according to Vulpius, in the Polish-Ukrainian Borderland (sic!) in the seventeenth century the word rossiiskii denoted all Eastern Orthodox Slavs. First and foremost, the term ruski (ruskii) was in most widespread use on those terrains. It had several meanings: ruski język (the Russian language), ruski pop (an Eastern Orthodox priest), ruski człowiek (Rusin - a Ruthenian), województwo ruskie (voivodeship - an administrative unit). In the eighteenth century, the word rosyjski (in the case of the seventeenth century - moskiewski, that is Muscovian) was primarily used in the context of Russia as a state - Muscovite Russia. ${ }^{6}$

${ }^{6}$ Stownik staropolski lists only the term ruski meaning 'relating to the Rus' region' and in the phrase pop ruski (an Eastern Orthodox priest) ('Ruski', in Słownik staropolski, 
Vulpius presents further semantic analyses also in the subsequent chapters. One of them is related to Poland. Comparing the meanings of the terms kholop and poddanyi with the similarly sounding Polish words chtop and poddany, Vulpius claims (citing Stownik staropolski, one of the two sources in Polish) that, unlike their Russian counterparts, Polish noblemen were not and did not consider themselves subjects of the Polish king. Allegedly, in Polish reality, the term poddany was only used to describe the relationship between Polish peasants and the king (pp. 87-88). In point of fact, according to the dictionary cited, the meaning of the word poddany is not limited to 'a commoner subject to the king' or 'a peasant subject to a feudal lord'. The term is also used to describe an inhabitant of a given state subjected to its authorities, for example the king. In that context, if Polish kings wrote poddani nasi, they had all the estates - nobility included - in mind. ${ }^{7}$

As the book indicates, the author has a predilection for dealing with concepts rather than actual events in a specific chronological framework; the latter are only sometimes used as examples. It is, therefore, accurate to see Vulpius as a representative of Begriffsgeschichte (conceptual history). This approach considers etymology and historical semantics as the key to understanding the transformations of paradigmatic ideas, culture, customs, and language. For instance, while discussing the term prosveshchene (Enlightenment), Vulpius writes that it only arose in Petrine times and was first used to denote converts to the Eastern Orthodox Church or the newly baptized members of this church (p. 220-21). In the second half of the eighteenth century, the term was 'secularised', becoming a semantic tool used to battle ignorance and wildness. Another term mentioned, barbarian (Ger. Barbar, Russian Varvar), initially used by Westerners to denote Russians ${ }^{8}$ was applied by Russians to non-Christian peoples when it first came into use in the Russian language. As Vulpius shows, few were ready

11 vols, ed. Stanisław Urbańczyk et al., Wrocław, 1953-2002, vol. 8, 1977, p. 47); also, the Słownik jezyka polskiego by Samuel B. Linde that the author is not familiar with, makes a distinction between rosyjski (Muscovian) and ruski (Ruthenian) ('Rossya' and 'Ruś', vol. 3, Warsaw, 1812, pp. 53, 145).

7 'Poddany', in Stownik staropolski, vol. 6, 1971, pp. 236-37 (p. 236, verses: 15-22, 30). The author cited this dictionary but only paid attention to the second meaning of the word 'poddany' that was listed. See also Krystyna Wilczewska and Alina Linda, 'Poddany', in Słownik polszczyzny XVI wieku, Wrocław and Warsaw, 1966- , vol. 25, ed. Franciszek Pepłowski, Warsaw, 1997, pp. 389-99.

${ }^{8}$ The author lists Polish propaganda among the sources of the image of Russia as a barbarian, tyrannical state (p. 208); as Polish research shows, Vulpius is right, for example Hieronim Grala, 'Jagiellonowie a Moskwa', in Europa Jagiellonica 1386-1572: Sztuka, kultura i polityka w Europie Środkowej za panowania Jagiellonów, ed. Przemysław Mrozowski, Paweł Tyszka and Piotr Węcowski, Warsaw, 2015, pp. 57-82 (pp. 75-80). 
to admit that the alleged 'barbarians' also included representatives of highly developed societies whose approach to Russia was 'unfavourable' (p. 228). The scholar also notes how the context in which the word 'wildness' (dikost') was used, changed. Initially, it appeared alongside words such as legkomyslie, vetrenost', nepostoianstvo, svoevolst, or neobujdennost'; by the end of the eighteenth century, the emphasis shifted to insufficient knowledge and education or an undesirable moral character (still, a certain negatively assessed deficiency was stressed). At the turn of the nineteenth century, the term once again changed its meaning under the influence of Enlightenment ideology ('noble savage'?), gaining a positive connotation (pp. 228-31). To Vulpius, all these lexical developments are closely associated with the civilizational idea that she discusses. However, the scholar does not examine whether these semantic shifts were caused by the spirit of the epoch or were the result of deliberate efforts on the part of the tsars (especially Peter I and Catherine II, who both strove to overtake the civilized countries, initiating legislation, encouraging historical work and lexicography, and later promoting their achievements in the West). I doubt that these semantic changes influenced the actual political practices of the state - these were effectively determined by the tsar's will alone. The examples presented in the book show that these changes pertained only to justifications (modified according to circumstances) rather than ends and means.

Chapter 2 is devoted to subjecthood (Untertanenschaft) as an instrument for empire-building. Vulpius begins with explaining basic terms - poddanstvo, kholop - their origin, and the criteria employed by the tsars to subject people and entire nations to their rule. As the scholar notes, Russian subjecthood did not resemble Western feudal relations based on at least some balance between the rights and duties of the vassal and his lord. Starting in the Middle Ages, the relationship between the tsar and his subjects was based on a unilateral, sovereign 'act of benevolence' on the tsar's part. The new subject had to plead an oath of allegiance, sworn on their god. Russian political thought presented this 'benevolence' as an instrument of making all subjects equal in their relationship to the tsar. However, it did not exclude the rule of 'flexibility' - that is modifying rules and requirements entirely dependent on the sovereign's will. The only change that the eighteenth century brought was that what initially was a personal relationship between a subject and the ruler slowly became subjecthood to the state at the end of the century (pp.93-94). As Vulpius concludes, subjecthood was an instrument of Russian expansionism and a means to transform Russian influences (Einmischung) and protection (Protektion) into real political power. The scholar makes an interesting observation: even when Russia 
did not trust in the oaths of the future subjects (as was the case with, for instance, Kazakhs), it demanded that they were taken; this reinforced the Russian 'eternal' right to subject different groups to its rule. The author concludes that flexibility (Flexibilität) and pragmatism concerning the administration of different territories while retaining the concept of the 'act of benevolence' was a consistent pattern in Russian politics (pp. 67-69). ${ }^{9}$ However, Vulpius also had to admit that subjecthood as a legal construction turned into actual subjugation with time, as it was often enforced by punitive expeditions and interference in internal affairs (Strafexpedititonen und Einmischungen) of the dependent territories.

Further on, the author gives a detailed account of the differences in understanding Russian protection and Russian subjecthood between the centre and the peripheries. Even though Vulpius leaves the question of the Empire's policy towards Left-bank Ukraine largely untouched, ${ }^{10}$ the matter appears indirectly in the context of the 1654 Pereiaslav Agreement and the subjection (Untertanenschaft) the Cossacks accepted. As the scholar notes, the Cossacks strove to formulate the agreement in the Western European political tradition vein, with both sides accepting their obligations. They failed - the tsar refused to reciprocate the oath of allegiance. From the Russian point of view, the situation ended in 'an act of benevolence' not a bilateral alliance. These fragments offer a fascinating context for the Polish-Lithuanian Commonwealth subjects seeking protection of Russia in the eighteenth century. The broad historical background informed by the past of other peoples and countries that secured the protection of Russia to be later incorporated into the empire can shed light on Polish history, too. It seems this research problem is not examined enough in Polish academia: how did the gentry and kings of the Polish-Lithuanian Commonwealth understand their obligations towards Russia when they asked the tsars for protection, mediation, or guarantees? ${ }^{11}$ How did the

${ }^{9}$ Vulpius gives the year 1637 as an example, when the Khan of the Golden Horde did not want to accept the position of the tsar's kholop (slave) - a term that until then was typical for oaths of allegiance. Russia agreed to use the term poddanyi (from Latin subditus) instead; the word was used in Russian-Polish relations, pp. 87-88.

${ }^{10}$ This problem is to be covered in Vulpius's separate work titled Vorübergehende Allianz oder dauerhafte Unterwerfung? Die Bedeutung des Abkommens von Perejaslav im Kontext des Russländischen Imperiums, in Revolution und Krieg, ed. Martin Schulze Wessel [Schriftenreihe der Deutsch-Ukrainischen Historikerkommission, vol. 1]. It is currently being prepared.

${ }^{11}$ Tomasz Szwaciński's works offer valuable insight into the matter: Tomasz Szwaciński, 'Protekcja rosyjska udzielana przedstawicielom szlachty litewskiej u progu wojny siedmioletniej: Postawienie problemu', KH, 118, 2011, 1, pp. 47-83; Szwaciński, 'Rosja a Piotr i Jan Sapiehowie w dobie kryzysu ostrogskiego (1754-1758)', KH, 119, 2012, 1, pp. 32-65; I discussed how Polish gentry started asking the Russian tsars for 
Russians understand it? What were the consequences of the discrepancies in the understanding of these acts? In her work, Vulpius remains focused on Russian imperial expansion to the east and south. Nevertheless, her considerations regarding semantics and the 'flexible methods' Russia employed towards nations subjected to imperial control offer valuable material for comparative analyses that may elucidate the Russian practices in the western areas, including Polish territories.

In Chapter 3, the author discusses the Russian tradition of hostage-taking (Geiselhaltung, amanatstvo) as an instrument of exerting power and control over the non-Christian parts of the Empire. Russian subjecthood could only be obtained by an oath (prisiaga, shert'), sometimes accompanied by a tribute (iasak); nonetheless, a hostage guaranteed the new subjects' loyalty. Vulpius describes how this custom grew increasingly common in Muscovite Russia in the sixteenth century and its transformations in the eighteenth century. She ponders on the practice's origins: was it a Mongolian tradition, a medieval practice known amongst South Slavs, or perhaps a custom dating back to Roman times? Vulpius gives a somewhat shocking proposition: amanatstvo became an inherent element of the Russian civilizatory mission, according to the scholar. She justifies it: the hostages learned the Russian language and absorbed Russian culture while taken to the centre. Once they came back to their native land, they spread the imperial influences and culture amongst their people. The author also claims Russia never took hostages from Christian nations incorporated into Russia (that is Ukraine, the Baltic provinces, and the land seized from the Polish-Lithuanian Commonwealth) (p.102) and reinforces the assertion when she writes: 'For nearly three hundred years hostage-taking was only practiced against non-Christian inhabitants of the tsarist country' (p. 189). ${ }^{12}$ This is not the whole truth. Indeed, when Muscovite Russia annexed the Smolensk region in 1654, no hostages were taken, and the populace was not resettled (as Tsar Ivan IV had done in the sixteenth century). Nonetheless, Russia used another method to extort loyalty from Ukraine: a large part of the Cossacks was resettled to the east, and many Russian officials were brought into the Ukrainian hetmanate. When Hetman Petro Doroshenko pledged allegiance to Russia in 1679, after numerous changes of front and allies, he was resettled far away from home to

political protection in: Urszula Kosińska, 'U źródeł zjawiska odwoływania się do potencji ościennych w polskich sporach wewnętrznych - casus roku 1730', SDRE, 54, 2019,1 , pp. 5-26. The problem has also been discussed elsewhere, but there is no monograph on the topic.

12 'Die Geiselnahme wurde über fast drei Jahrhunderte nur gegenüber nicht Christen des Zarenreiches praktiziert'. 
Viatka; he never returned to Ukraine. After Hetman Mazepa's betrayal (izmene), his family (wives and children) and supporters were forcibly resettled to Russia and effectively treated as hostages - prisoners who were investigated, deprived of their income, and whose private correspondence was controlled. ${ }^{13}$

Another telling example: in 1770 Ghica, prince of Wallachia (undoubtedly (hristian), who was detained in winter that year by the Russians in Bucharest, was given a friendly reception in St Petersburg with honours, together with his cousin and the son of the deceased prince of Moldavia Mauro Corado. A hotel was rented out for them at the expense of the Russian court and fitted with imperial equipage. They also had an official audience with count Panin and were presented to Catherine the Great. However, as he admitted in a conversation with Solms, a Prussian envoy, the prince considered himself the empress's prisoner. ${ }^{14}$

In this context, it is interesting to consider how to classify the status of Polish senators kidnapped in 1767 from Warsaw and imprisoned until 1773 in Kaluga - undoubtedly, the men were prisoners; they were not, however, prisoners of war, as Russia was not at war with Poland in 1767. They were not typical hostages taken to compel the country to respect the treaties. Nonetheless, as Kazimierz Rudnicki pointed out, they were treated as such - the senators were intimidated by threats of further cruel repressions of prisoners in Warsaw in order to influence the Polish delegation that still partially resisted Russia's demands, refusing to sign the so-called treaty of guarantee.$^{15}$ Perhaps the most revealing case is a Christian ruler of a Christian country, held captive by Russian guards in Grodno (the appearances of royal ceremonial were kept, notwithstanding) - namely, the Polish king Stanisław II August, treated by Russia as a hostage and guarantor of the humiliating conditions of the surrender of the Kościuszko Uprising and the final partition of Poland. ${ }^{16}$ As these examples show, had the perspective of the western territories not been

${ }^{13}$ Nikolai I. Kostomarov, 'Mazepa i mazepincy', in idem, Sobranie sochinenii: Istoricheskiia monografii i izsliedovaniia, 8 books, St Petersburg, 1903-06, book 6, vol. 16, 1905, for example pp. 747-50, 759, 770-78; Anton Jensen, 'Orlyk u Shvetsiï', Zapysky Naukovogo tovarystva imeni Shevchenka, 18, 1909, 92, pp. 93-169 (p. 100).

${ }_{14}$ Prussian envoy to St Petersburg Victor Friedrich Solms to Frederick II King of Prussia, 19 February/2 March and 5/16 March 1770, no. 598 and 601, Geheimes Staatsarchiv Preußischer Kulturbesitz (GStAPK) Berlin-Dahlem, I Hauptabteilung, Rep. 96, no. 57D special thanks to Dorota Dukwicz, PhD., for bringing this example to my attention.

${ }^{15}$ Kazimierz Rudnicki, Biskup Kajetan Sołtyk: 1715-1788, Cracow and Warsaw, 1906, p. 186.

${ }^{16}$ The royal family was treated like hostages after the failure of the Kościuszko Uprising. They were kept in Warsaw and denied passports. Maria Żywirska, Ostatnie 
disregarded, the author might have developed a deeper understanding of the problems she tackled. As we can see, there is a research gap in this field - the governing practices of Russia in eighteenth century Poland in the context of the political ideas prevalent in the Russian Empire need to be further examined in academia. A broad comparative analysis could bring interesting results. Vulpius's work undoubtedly provides a theoretical and semantic basis for the task.

Chapter 4, the most extensive in the book, has six sections, each with its own conclusion. Vulpius discusses the civilizational and assimilatory (Zivilisierung und Eingliederung) concepts and practices adopted by Russia with regard to the eastern and southern parts of the empire. The author starts with an analysis of the terms Zivilisiertheit and Zivilisation and the discourse they are central to, namely to what extent the self-civilization of Russian people is connected to the civilization of non-Russian groups. Vulpius describes the Russian engagement in building fortresses and fortification lines on the newly acquired terrains and the significance of this policy for the civilizatory and imperial process. Again, it appears that the chronological framework the title of the book suggests needs to be extended as the origin of the phenomenon dates back to the mid-sixteenth century when Muscovite Russia needed protection from the invasions of steppe peoples. The purpose of the fortifications changed in the eighteenth century; in 1694, Peter I decided to extend the range of fortifications and adapt them to the use of artillery. From that moment on, the fortifications ceased to serve a merely protective function. They became a typical instrument of power on a militarized border - bases facilitating the organisation of punitive expeditions (Strafexpeditionen) to the borderlands. The fortifications cutting across the traditional migration terrains of nomadic peoples became an element of Russian 'civilizatory' policy aimed at populating the vast empty areas to integrate them with the centre later. To this end, nomadic groups were forcibly settled and encouraged to colonize the land. Another tactic was to send the populace living along the Dnieper or the Don (the Cossacks, but also prisoners of war and exiles, the so-called nevol'nye migranty) ${ }^{17}$ to distant garrisons.

\footnotetext{
lata życia króla Stanisława Augusta, Warsaw, 1975, p. 23; Jerzy Michalski, Stanisław August Poniatowski, PSB, vol. 41, Warsaw and Cracow, 2002, pp. 632-33.

${ }^{17}$ These insights also apply to Polish prisoners of war - the Bar Confederates, see for example Anna A. Krih, Svetlana A. Mulina, 'Pol'skie konfederaty v Sibiri', Izvestiia Irkutskogo gosudarstvennogo universiteta. Seriia: Politologiia. Religiovedenie, 2012, 2 (9), part 2, pp. 13-21; Swietłana Mulina, 'Jeńcy-konfederaci w perspektywie rosyjskich problemów i konfliktów społecznych', in Konfederacja barska 1768-1772, ed. Adam Danilczyk, Warsaw, 2018, pp. 113-23.
} 
The role of Eastern Orthodoxy and the state 'missionary' policy in the territories discussed is another crucial problem. As the author writes, before Petrine times Russia had no 'missionary policy', and the word missiia, derived from Latin, appeared in Russian relatively late through the Polish language (p. 282). According to Vulpius, in the sixteenth and seventeenth century Russia limited its religious politics to state-sponsored baptisms of pagans. The newly-baptized were incorporated into the ranks of Boyar scions; men were enrolled into the army, and the converted women were married off to Russians. In most cases, the converts stayed in Russia once they came back to their kin, they mostly returned to their old beliefs. As the author notes, Peter I, Anna Ivanovna, and Elizabeth Petrovna intensified the missionary action. Military and administrative pressure increased. The newly acquired terrains were supposed to form a part of the Christian cultural landscape (an end achieved by means of Orthodox churches) and become centres of Christian customs. To achieve this aim, sanctions against those unwilling to convert (such as the confiscation of private property) were introduced alongside the privileges for the newly baptized. As Vulpius shows, this is how the state-sponsored missionary action effectively became one of the means to build a police state (p. 309). In the eighteenth century, these processes became increasingly interwoven with central regulations regarding the local economy and lifestyle. The author pays particular attention to the settlement of nomadic peoples resulting in changes introduced to former laws and, most importantly, the transformation of pre-existing social structures in accordance with Russian interest so that the people did 'chego gosudarstvennoi interes ot nikh trebuet' (p. 424).

It would be impossible to discuss all issues tackled by Ricarda Vulpius. I have therefore decided to pay special attention to the Polish context. It is mainly unexamined, as the author decided to refrain from looking into the concepts and practices of Russian rule in the western parts of the empire. What follows is a series of inaccuracies or even occasional mistakes. Poland and the Polish-Lithuanian Commonwealth are mentioned only sixteen times, including two instances when Poland appears in the title of a cited work. There are several mentions (without commentary) of the Russian annexation of distinct national territories, including the partitions of Poland ('Teilungsgebiete Polens': pp. 30, 37, 51, 189, 511). What strikes me is that writing about the 1654 annexation of Smolensk and Left-bank Ukraine (consistently referred to as 'Hetmanate-Ukraine'), the author does not mention that these terrains previously belonged to the Polish-Lithuanian Commonwealth (p. 30). In the book, there are also three instances when Vulpius notes the significant influence of the Polish lan- 
guage on Russian vocabulary - specifically, the terms liudkost', politichnii, missiia - that arose in Petrine times (pp. 201, 212-13, 282).

Vulpius mentions the partitions of Poland very briefly in a footnote. The scholar claims that the manifesto issued by Catherine II to justify the territorial division of the country (as the context suggests, the event in question is the first partition of Poland in 1772) exhibits elements of Russian civilization discourse that also surrounded the peoples in the south and east of the empire - the dominated groups were accused of disorder, anarchy and religious fanaticism; the population should therefore be protected from 'wildness'. ${ }^{18}$ A correction needs to be made here: the partition manifesto addressed to Poles (and the text of the 1772 partition treaty) does mention the anarchy reigning in Poland and presents it as a risk to the Russian populace. There is, however, no reference to the alleged religious intolerance in Poland - even though in previous years Russia insistently used this accusation to justify intervention in Poland's affairs. ${ }^{19}$ Vulpius also claims that the 'discourse' in question was not followed by a policy of external control over Polish society as a whole, as was the case with the nations inhabiting the eastern and southern parts of the Russian empire. ${ }^{20}$ This conclusion seems somewhat hasty - the author neither performed a comparative analysis nor examined the numerous secondary sources on Russian policy towards Poland in the period following the partitions. The only work on the topic Vulpius cites is Polen und Russland by Klaus Zernack. Anyone familiar with how Russia first made certain terrains of the Polish-Lithuanian Commonwealth politically dependent on the empire in order to annex them can give numerous examples of Russian actions aimed at gaining increasing control over the Commonwealth, both before and after the partitions. They were, by and large, analogous

18 'So lassen sich in der Begründung mit der Katharina II. die Teilung Polens rechtfertigte, Elemente eines Zivilisierungdiscurses finden, wonach Unordnung, Anarchie und religiöser Fanatismus bekämpft und die Bevölkerung vor, "Verwilderung" geschützt werden müsse', Vulpius, pp. 36-37, note 84.

${ }^{19}$ Jacek Kordel, Królestwo anarchii, Warsaw, 2020, pp. 253-56; text of the declaration: Deklaracja jednosłowna oddana ministrom króla imci i Rzeczypospolitej Polskiej przez ichmość pp. de Stackelberg, de Benoit..., 26 September 1772, in Zbiór deklaracyi, not i czynności główniejszych, które poprzedziły i zaszły podczas sejmu pod węzłem konfederacyi odprawującego się od dnia 18 września 1772 do 14 maja 1773, s.l.e.a., p. 1-5; the Russo-Prussian treaty, 4/15 January 1772 in Sobranie traktatov $i$ konventsii, zakliuchennykh Rossiei s inostrannymi derzhavami, published by Fedor F. Martens, 15 vols, St Petersburg, 1874-1909, vol. 6, 1883, pp. 71-85.

20 'Dem Discurs folgte nicht eine vergleichbare Politik der gesamtgesellschaftlichen Fremdsteuerung, wie sie gegenüber den Völkern des Ostens und Südens praktiziert wurde', Vulpius, p. 37, note 84. 
to the treatment the southern and eastern territories received: the presence of the Russian army, the so-called rzady ambasadorskie (that is a situation when the ambassadors of the Russian Empire held positions that were de facto superior to the local authority), blocking corrective measures, support for political opposition, punitive expeditions, confiscations, kidnappings, putting pressure on legitimate local authorities, exerting influence on the local legislative process, blackmailing the king, economic exploitation and so on. ${ }^{21}$ It is probable the author herself believes in numerous accusations of intolerance directed at Poles, expressed both in sources and the public sphere; it seems Vulpius adopted these views as her own without much criticism. In this context, the information (p. 259) about the alleged victims of religious persecution from Poland ('religiös Verfolgte aus Polen') $)^{22}$ that were resettled to uninhabited Siberian steppe sounds rather peculiar. This line of thinking is also apparent when Vulpius classifies the Poland-Lithuanian Commonwealth of the seventeenth century as an intolerant state, resembling France or the Habsburg countries in that respect (p. 298) and calls eighteenth century Poland 'an exclusively Roman Catholic country'. In fact, numerous religious minorities inhabited the country: Jews, Greek Catholics, Eastern Orthodox, Lutherans, and others (p. 310).

As Vulpius elaborates on the fortifications built by Muscovite Russia in the sixteenth and seventeenth centuries to protect the land from incessant invasions, she commits mistakes due to her misconceptions about the Polish-Lithuanian Commonwealth. She sees the Russian initiatives as a testimony to military and economic power and juxtaposes this alleged strength to the weakness of both the Polish-Lithuanian Commonwealth and the Ottoman Empire (sic!), two countries that did not construct similar fortifications (p. 239). ${ }^{23}$ Vulpius does not mention that in the case of Poland, what was at stake was not the weakness of the state as such - in

${ }^{21}$ Andrzej Nowak, 'Poligony imperialnej polityki: między Barem, Krymem, Kaukazem', in Konfederacja barska: Jej konteksty, tradycje, ed. Anna Buchmann and Adam Danilczyk, Warsaw, 2010, pp. 131-56; A. Nowak notices a significant similarity in the methods employed by Russia in the Poland-Lithuanian Commonwealth during the times of the Bar Confederation and the tactics employed to conquer Crimea and Caucasus. The scholar also notes that when Catherine II commissioned Voltaire to write about Russia as the 'apostle of civilization in the East', she also pointed to Poland as a 'blank spot on the Enlightenment map', waiting for its 'apostles of civilization', p. 132.

${ }^{22}$ It is a known fact that from the times of Augustus II until the era of Stanisław August, the Russian army crossed Polish borders and kidnapped the local populace under the pretext of searching for fugitive Russian subjects. The abducted people were later sent as settlers to distant parts of the empire that lacked an agricultural population.

${ }^{23}$ 'Er war Ausdruck eines erstarkten Moscauer Reiches, das im Gegensatz zu seinen 
fact, the authorities were reluctant to make significant investments because the leading ideology of the nobility saw them as tools for building an absolute monarchy.

Another matter Vulpius does not discuss is the eighteenth century Russian imperial policy of creating a system of states that were not officially incorporated into the Empire yet remained heavily dependent on Russia, politically or economically. These included the Polish-Lithuanian Commonwealth before the partitions, Courland, also Mecklenburg and Sweden for a certain period. The scholar also fails to understand Russian imperialism as a process of extending spheres of influence, providing protection to entire nations or religious groups that lived on the territories of other sovereign states (such as the Eastern Orthodox minority living in the Ottoman Empire), involvement in international affairs as a mediator and guarantor (for example during the War of the Bavarian Succession). Eventually, during the French Revolution, Russia became an inherent part of the European balance of power. All of these processes allowed Russia to become an empire and be considered one by European states.

In the closing chapter, the author claims that what was distinct about Russian imperial rule was that... there is nothing distinct about it. According to Vulpius, both the discourse and practices of civilization, acculturation, and assimilation exhibit numerous parallels to the ideas and actions of other colonial states, such as France, Spain, or Portugal. It is debatable whether the scholar proved these alleged similarities successfully. The (relatively few) examples she gives could also perhaps be accused of presentism.

It should nonetheless be noted that Ricarda Vulpius's book, which is a challenging read due to its hermetic and highly specialized terminology, deserves the attention of Polish readers. Clearly, we are not obliged to agree with all the interpretations given by the author. Her work undoubtedly presents certain schemata of subjugating newly acquired terrains (including local and contingent variations): military conquest, subordination granted by treaties, administrative and legal assimilation, and, finally, various sorts of acculturation: semantic, religious, cultural.

It should be stressed that there are, in fact, no Polish-language works that would offer a detailed investigation of how Russian imperial thought developed in the early modern period or the pre-nineteenth century governing practices employed in the eastern and southern borderlands of the

Nachbarn, dem Osmanischen Reich und Polen-Litauen, sowohl die Kräfte als auch die finanziellen Mittel besaß, um sich gegen die notorischen Einfälle zu schützen', p. 239. 
Empire. Even though the scholar limited the thematic scope of the book (that is decided not to tackle the governing practices employed by the empire in dealing with its western territorial acquisitions: the terrains seized from the Poland-Lithuanian Commonwealth in the seventeenth and eighteenth century and the Baltic region gained in the Great Northern War), the work still offers valuable insight into several problems regarding the development of terms, concepts, and governing methods Russia employed in dealing with territories inhabited by non-Russian and non-Christian peoples. As Andrzej Nowak already noted, this account allows for observing numerous similarities between Russia's methods in the Poland-Lithuanian Commonwealth and the empire's tactics employed in its southern and eastern borderlands. The book also inspires further questions that are of great interest to Polish scholars: for instance, on the protection granted to representatives of the Polish gentry that started in Petrine times, or the importance of Russian guarantees, a practice that the empire usurped in 1717 and secured in 1768 . Were these tools used to prepare for the processes of 'subjecting' Polish citizens to the Russian tsar and 'incorporating' Poland into the empire? Finally, how to understand the attempts to assimilate and acculturate the Polish nation in the post-partition era (attempts that, luckily, ultimately failed)? Without a shadow of doubt, Die Geburt des russländischen Imperiums by Ricarda Vulpius is an inspiring work.

(Translated by Natalia Sajewicz)

(Proofreading by Jan Czarniecki)

\section{Summary}

The paper is inspired by Ricarda Vulpius's book Die Geburt des russländischen Imperiums: Herrschaftskonzepte und -praktiken im 18. Jahrhundert by Ricarda Vulpius (Vienna, Cologne and Weimar: Böhlau, 2020), a publication that tracks the emergence of the conceptual background for governing the growing Russian Empire in the eighteenth century, when territorial gains rendered the country increasingly multinational, multi-faith and multicultural. It presents specific schemata of subjugating newly acquired terrains (including local and contingent variations): military conquest, subordination granted by treaties, administrative and legal assimilation, and, finally, various sorts of acculturation: semantic, religious, cultural. While the scholar limited the thematic scope of the book (that is decided not to tackle the governing practices employed by the empire in dealing with its western territorial acquisitions: the terrains seized from the Poland-Lithuanian Commonwealth in the seventeenth and eighteenth century and the Baltic region gained in the Great Northern War), the work still offers valuable 
insight into several problems regarding the development of terms, concepts, and governing methods Russia employed in dealing with territories inhabited by non-Russian and non-Christian peoples. The book also inspires further questions that are of great interest to Polish scholars: for instance, on the protection granted to representatives of the Polish gentry that started in Petrine times, the subjugation of Polish citizens to Russian rule, the 'incorporation' into the empire, and, finally, the attempts to assimilate and acculturate the Polish nation (attempts that, luckily, ultimately failed).

(Translated by Natalia Sajewicz) (Proofreading by Jan Czarniecki)

\section{Bibliography}

\section{Primary sources}

Sobranie traktatov i konventsii, zakliuchennykh Rossiei s inostrannymi derzhavami, published by Fedor F. Martens, 15 vols, St Petersburg: Tipografiia Ministerstwa Putei Soobshcheniia, 1874-1909, vol. 6, 1883.

Zbiór deklaracyi, not i czynności główniejszych, które poprzedziły i zaszły podczas sejmu pod węzłem konfederacyi odprawującego się od dnia 18 września 1772 do 14 maja 1773, s.l.e.a.

\section{Secondary literature}

Grala, Hieronim, 'Jagiellonowie a Moskwa', in Europa Jagellonica 1386-1572: Sztuka, kultura i polityka w Europie Środkowej za panowania Jagiellonów, ed. Przemysław Mrozowski, Paweł Tyszka and Piotr Węcowski, Warsaw: Arx Regia, 2015, pp. 57-82.

Jensen, Anton, 'Orlyk u Shvetsii', Zapysky Naukovogo tovarystva imeni Shevchenka, 18, 1909, 92, pp. 93-169.

Kordel, Jacek, Królestwo anarchii: W poszukiwaniu nowożytnych wyobrażeń o Rzeczypospolitej i jej mieszkańcach, Warsaw: Narodowe Centrum Kultury, 2020.

Kosińska, Urszula, 'U źródeł zjawiska odwoływania się do potencji ościennych w polskich sporach wewnętrznych - casus roku 1730',SDRE, 54, 2019,1, pp. 5-26.

Kostomarov, Nikolai I., 'Mazepa i mazepincy', in idem, Sobranie sochinenii: Istoricheskiia monografii i izsledovaniia, 8 books, St Petersburg: Tipografiia M.M. Stasiulevicha, 1903-06, book 6, vol. 16, 1905, pp. 379-789.

Krih, Anna A. and Svetlana A. Mulina, 'Pol'skie konfederaty v Sibiri', Izvestiia Irkutskogo gosudarstvennogo universiteta. Seriia: Politologiia. Religiovedenie, 2012, 2 (9), part 2, pp. 13-21.

Linde, Samuel B., Słownikjęzyka polskiego, 6 vols, Warsaw: Drukarnia XX. Pijarów, 1807-14, vol. 3, 1812.

Michalski, Jerzy, 'Stanisław August Poniatowski', PSB, vol. 41, Warsaw: Instytut Historii PAN; Cracow: PAU, 2002. 
Mulina, Swietłana, 'Jeńcy-konfederaci w perspektywie rosyjskich problemów i konfliktów społecznych', in Konfederacja barska 1768-1772, ed. Adam Danilczyk, Warsaw: Wojskowy Instytut Wydawniczy and Neriton, 2018, pp. 113-23.

Nowak, Andrzej, 'Poligony imperialnej polityki: między Barem, Krymem, Kaukazem', in Konfederacja barska: Jej konteksty, tradycje, ed. Anna Buchmann and Adam Danilczyk, Warsaw: DiG, 2010, pp. 131-56.

Roćko, Agata, Pamiętniki polskich zesłańców na Syberię w XVIII wieku, Olsztyn: Wydawnictwo Uniwersytetu Warmińsko-Mazurskiego, 2001.

Rudnicki, Kazimierz, Biskup Kajetan Sołtyk: 1715-1788, Cracow and Warsaw: [n. pub.], 1906.

Stownik polszczyzny XVI wieku, Wrocław and Warsaw, 1966- , vol. 25, ed. Franciszek Pepłowski, Warsaw: Instytut Badań Literackich PAN, 1997.

Słownik staropolski, 11 vols, ed. Stanisław Urbańczyk et al., Wrocław: Zakład Narodowy im. Ossolińskich, 1953-2002, vol. 6, 1971, vol. 8, 1977.

Szwaciński, Tomasz, 'Protekcja rosyjska udzielana przedstawicielom szlachty litewskiej u progu wojny siedmioletniej: Postawienie problemu', KH, 118, 2011, 1, pp. 47-83.

Szwaciński, Tomasz, 'Rosja a Piotr i Jan Sapiehowie w dobie kryzysu ostrogskiego (1754-1758)', KH, 119, 2012, 1, pp. 32-65.

Wieliczko, Mieczysław, Jeniectwo wojenne Polaków w Rosji w latach 1503-1918, Lublin: Wydawnictwo Uniwersytetu Marii Curie-Skłodowskiej, 1998.

Żywirska, Maria, Ostatnie lata życia króla Stanisława Augusta, Warsaw: Państwowy Instytut Wydawniczy, 1975.

Biography: Ph.D. Urszula Kosińska works at the Faculty of History of the University of Warsaw. Her research interests include the eighteenth century, especially the history of the Polish-Saxon Union and Polish parliamentarism. E-mail: u.kosinska@uw.edu.pl. 